$\underline{\text { Review }}$

\title{
BIOSOLIDS AND HEAVY METALS IN SOILS
}

\author{
Maria Lucia Azevedo Silveiraㄹ ${ }^{1}$ Luís Reynaldo Ferracciú Alleoni ${ }^{2}$; Luiz Roberto Guimarães \\ Guilherme $^{3}$ \\ ${ }^{1}$ University of Florida, Dep. of Soil and Water Sciences, 32611, Gainesville, FL, USA. \\ ${ }^{2}$ USP/ESALQ - Dep. de Solos e Nutrição de Plantas, C.P. 09 - 13418-900 - Piracicaba, SP - Brasil. \\ ${ }^{3}$ UFLA - Dep. de Ciência do Solo, C.P. 37 - 37200-000 - Lavras, MG - Brasil. \\ *Corresponding author <lrfalleo@esalq.usp.br>
}

\begin{abstract}
The application of sewage sludge or biosolids on soils has been widespread in agricultural areas. However, depending on their characteristics, they may cause increase in heavy metal concentration of treated soils. In general, domestic biosolids have lower heavy metal contents than industrial ones. Origin and treatment method of biosolids may markedly influence their characteristics. The legislation that controls the levels of heavy metal contents in biosolids and the maximum concentrations in soils is still controversial. In the long-term, heavy metal behavior after the and of biosolid application is still unknown. In soils, heavy metals may be adsorbed via specific or non-specific adsorption reactions. Iron oxides and organic matter are the most important soil constituents retaining heavy metals. The $\mathrm{pH}, \mathrm{CEC}$ and the presence of competing ions also affect heavy metal adsorption and speciation in soils. In solution, heavy metals can be present either as free-ions or complexed with organic and inorganic ligands. Generally, free-ions are more relevant in environmental pollution studies since they are readily bioavailable. Some computer models can estimate heavy metal activity in solution and their ionic speciation. Thermodynamic data (thermodynamic stability constant), total metal and ligand concentrations are used by the GEOCHEM-PC program. This program allows studying heavy metal behavior in solution and the effect of changes in the conditions, such as $\mathrm{pH}$ and ionic strength and the application of organic and inorganic ligands caused by soil fertilization.
\end{abstract}

Key words: sewage sludge, adsorption, speciation, $\mathrm{pH}$, organic matter

\section{BIOSSÓLIDOS E METAIS PESADOS EM SOLOS}

RESUMO: A aplicação agrícola de lodos de esgoto ou biossólidos tem se tornado prática comum, mas pode causar o acúmulo de metais pesados nos solos, dependendo das características desses resíduos. Em geral, biossólidos de origem doméstica apresentam teores de metais inferiores aos dos oriundos de descarga industrial. A origem e o processo de tratamento influenciam as características desses materiais. A legislação que controla os níveis de metais pesados presentes nos biossólidos e a concentração máxima nos solos é controversa. $\mathrm{O}$ comportamento dos metais pesados em longo prazo, após o término da aplicação de biossólidos, não é bem conhecido. Nos solos, os metais pesados podem ser adsorvidos por meio de reações de adsorção específica e/ ou não específica. Dentre os componentes que retém metais pesados, destacam-se os óxidos de Fe e a matéria orgânica. $\mathrm{O}$ pH, a CTC e a presença de cátions afetam a adsorção e a especiação iônica de metais pesados nos solos. Em solução, os metais encontram-se como íons livres e/ou formam complexos com ligantes orgânicos e inorgânicos. As espécies-livres são mais importantes em estudos de poluição ambiental, pois correspondem às formas prontamente biodisponíveis. Alguns programas computacionais calculam a atividade dos metais em solução e sua especiação iônica. O programa GEOCHEM-PC utiliza uma base de dados termodinâmicos (constante de estabilidade termodinâmica), a concentração total do metal e dos ligantes em solução. Isso permite observar o comportamento dos metais em solução e a resposta dos mesmos às mudanças nas condições do meio, tais como a variação do $\mathrm{pH}$ e da força iônica e a adição de ligantes orgânicos e inorgânicos via adubação.

Palavras-chave: lodo de esgoto, adsorção, especiação, pH, matéria orgânica

\section{INTRODUCTION}

Industrialized societies produce large amounts of waste and one of the options for its disposal is through application on agricultural land. Since 1970, the interest in spreading sewage sludge from municipal sewage treat- ment plants on agricultural and forested land as a nutrient subsidy is steadily increasing (Tomlin et al., 1993). Nearly half of the sludge production in the United States is currently being applied to lands. In the European Community, over $30 \%$ of the sewage sludge is used as fertilizer in agriculture. Agricultural land application appears 
to be a logical and reasonable use, since it may improve many soil properties, such as $\mathrm{pH}$ and the contents of organic matter and nutrients (Tsadilas et al., 1995; LópezMosquera et al., 2000, Sastre et al., 2001). Sewage sludge is effective as a fertilizer, increases dry matter yield of many crops (Tsadilas et al., 1995), and can also improve soil physical properties such as porosity, aggregate stability, bulk density, and water retention and movement (Karapanagiotis et al., 1991).

In the United States, the application of sewage sludge is controlled by the U.S. Environmental Protection Agency (USEPA Clean Water Act 503 Regulations) (United States, 1993). The USEPA 503 rule (standards for the use or disposal of sewage sludge) controls the application of biosolids at agronomic rates appropriated for crop yield. The term "sewage sludge" is used in many references because of its wide recognition, its regulatory definition, and its consistency with other EPA 503 guidance documents. However, the term "biosolids" is becoming more common as a replacement for "sewage sludge", because it is thought to reflect more accurately the beneficial characteristics inherent to sewage sludge.

The use of biosolids in cropland and forested land may be restricted by their heavy metal contents. Heavy metals most commonly found in biosolids are lead $(\mathrm{Pb})$, nickel $(\mathrm{Ni})$, cadmium $(\mathrm{Cd})$, chromium $(\mathrm{Cr})$, copper $(\mathrm{Cu})$, and zinc ( $\mathrm{Zn})$, and the metal concentrations are governed by the nature and the intensity of the industrial activity, as well as the type of process employed during the sewage sludge treatment (Mattigod \& Page, 1983). Usually, domestic waste has lower heavy metal contents than industrial waste. Pires \& Mattiazzo (2003) demonstrated that the bioavailability of metals could be enhanced in biosolids treated with polymers, when compared to ferric chloride and calcium oxide treatments. The bioavailability of metals is directly related to the chemical characteristics of the biosolid and of the soil.

The long-term use of sludge can cause heavy metal accumulation in soils (López-Mosquera et al., 2000). Even after short-time application of biosolids, the levels of heavy metals in soils can increase considerably. Oliveira \& Mattiazzo (2001) observed increases in $\mathrm{Cu}$, $\mathrm{Cr}$, Ni e $\mathrm{Zn}$ concentrations in soils amended for two years with biosolids. Heavy metals can also contaminate the food chain and reduce crop yields (Obrador et al., 1997; Wang et al., 2003).

The consumption of plants containing high levels of heavy metals might pose a serious risk to human health (Turkdogan et al., 2003; Wang et al., 2003). Depending on the environmental conditions and the rate that heavy metals are added to the soils, these elements can be leached through the soil profile, and consequently, contaminate groundwater. Antoniadis \& Alloway (2003) studied soils that received heavy loads of biosolids and pointed out that the movement of heavy metals was sig- nificant down to the $0.8 \mathrm{~m}$ soil depth, suggesting the risks of applying this residue for a long period. Since heavy metals do not break down, they might affect the biosphere for a long time. Wang et al. (2003) investigated heavy metal contamination in soils and plants at polluted sites in China, and reported the problems associated to the consumption of rice grown in paddy soils contaminated with $\mathrm{Cd}, \mathrm{Cr}$ or $\mathrm{Zn}$, because 22 to $24 \%$ of the total metal content in the rice biomass was concentrated in the grain.

The sludge can introduce excessive amounts of nutrients, mainly nitrogen and phosphorus, pesticides and pathogenic microorganisms to soil (Barry et al., 1995). Soil salinity can also be affect by sludge application and, consequently, the metal availability to plants may become higher. Therefore, the risk of soil contamination by heavy metals must be considered when biosolid is applied, and an understanding of the behavior of heavy metals in the soil is essential for assessing environmental risks when these metals are incorporated by the agroecosystem.

\section{PLATEAU AND TIME BOMB THEORIES}

The plateau and time bomb theories are opposite philosophies used to explain metal behavior in soils and their uptake by plants in response to biosolid application on agricultural areas. The plateau theory considers that biosolids may prevent the excessive metal uptake by plants. This protective effect is attributed to the presence of organic matter in this residue. On the other hand, the time bomb hypothesis considers that the slow mineralization of the organic matter present in biosolids could release metals in readily soluble forms, which then may become available for plant uptake.

Plant uptake differs depending on the metal source. When metals are added to soils as soluble salts, a linear response is expected; in other words, as the concentration of metal increases in the soil, there is an increase in the metal concentration in the plants. On the other hand, when metals are added to soils as biosolids, a "plateau response" occurs in plant uptake. This plateau effect is related to the presence of adsorptive materials in the biosolid, such as organic matter and amorphous iron oxides. In general, these compounds are very stable and exhibit high adsorbing affinity to metals. The fraction of organic matter present in the biosolids, which provides protection against metal uptake, can resist to decomposition (McBride, 1995).

Soils compete for biosolid-bound metals and plant uptake increases when initial amounts of biosolids are added to soils. As more biosolids are added, the strong binding sites of the biosolid matrix become dominant over the binding sites in the soil, resulting in a "plateau effect" in relation to plant uptake. At that point, the metal absorption by plants does not increase in response to biosolid application and this is known as the "plateau theory". For the plateau to occur during the land application of biosolids, some conditions are necessary, such as: 
1) Before the plateau is reached, continuing application of sludge will result in increasing metal concentration in plant tissue. If the application is stoped, the metal concentration in plant tissues will be the same as that at the termination time;

2) After the plateau is reached, continuing application of sludge results in metal concentrations in plant tissues equal to those found during the plateau. If application terminates, the metal concentrations in plant tissue will be the same as those of the plateau (Chang et al., 1997). These studies on the "plateau effect" reject the hypothesis of the "time bomb", which states that the slow mineralization of the organic matter of the sludge could release the metals in more soluble forms (McBride, 1995).

The time bomb hypothesis concerns about the consequences of the metal concentration in soil and in plant tissue following the termination of biosolid application. Data obtained from a 10 -yr field submitted to biosolid land application, show that $\mathrm{Cd}$ concentration in soils and in plant tissue increased with increasing biosolid application, and that no plateau was reached, even at a loading mass reaching 1,080 $\mathrm{t} \mathrm{ha}^{-1}$ (Chang et al., 1997). Although there was no plateau, ten years after the termination of biosolid application, the metal concentration in plant tissue did not rise. This fact indicates that neither the plateau nor the time bomb hypothesis are realistic.

\section{LEGISLATION CONTROLLING BIOSOLID AP- PLICATION}

When compared to international standards, the USEPA regulations are permissive for most metals, and their premises have been extensively criticized (McBride, 1995; Schmidt, 1997). The maximum permitted accumulation defined for heavy metals $(\mathrm{Cd}, \mathrm{Cr}, \mathrm{Cu}, \mathrm{Mo}, \mathrm{Hg}, \mathrm{Ni}$, $\mathrm{Pb}$ and $\mathrm{Zn}$ ) and nonmetal elements (As and $\mathrm{Se}$ ) in soils can be 10 to 100 times greater than the original concentration present in most of soils (McBride, 1995). In the land application risk assessment, 14 pathways were evaluated by USEPA as possible pollutant transfer routes from land-applied biosolid to plant, animals or humans, and the land application of biosolids must meet either pollutant loading rate limits, or annual pollutant loading rate limits for the metals present in the residue (United States, 1994).

To develop the USEPA 503, greenhouse studies were carried out in which soluble metal salts and biosolids were added to soil in pots to determine uptake of pollutants and phytotoxicity from pollutants of the biosolids. Metal salt and pot studies greatly overestimated phytotoxicity and bioavailability of metals (United States, 1994). When heavy metals were applied as biosolids, certain components such as ferric hydrous oxides, organic matter and phosphates, bind metals to the residue, making them less available to plants, animals and humans. Based in these results, the plateau theory was used to de- velop USEPA 503. For biosolids containing low levels of pollutants, additional cumulative amounts of pollutants added to land are not required, and its use is allowed within minimal regulatory oversight.

Although the protection of plants is an important aspect of USEPA 503, the interspecies sensitivity, the selection of phytotoxicity threshold, and the relationship between trace element application rates and plant uptake rates was not considered when this regulation was developed (Schmidt, 1997). Nevertheless, it would be impossible to determine the phytotoxicity threshold for the entire range of possible natural conditions, such as plant species, soil types, and environmental conditions. The USEPA calculated the metal uptake coefficient (UC) using tissue analyses for the edible part of crops growing in sludge-treated fields. The UC coefficient obtained for crops cultivated in one or more sludge treatment levels was compared to metal concentration in control crops. However, it was reported that, in some cases, the metal concentrations in control crops were very high, suggesting sample contamination, such as contamination by soil particles and atmospheric deposition, or inappropriate analytical techniques (McBride, 1998). This author suggested that the UC inaccuracy might be unsuitable for use in risk assessments.

Even though some studies have shown that phytotoxicity only occurs when biosolids with high metal concentrations are applied at high rates, or when soils exhibited very low pH (below 5.0) (United States, 1994), the long term implication of metal availability to plants cultivated in biosolid-treated soil is uncertain. The USEPA 503 was based in short-term experiments at relatively low metal loadings, and a question remains: "what happens to toxic metals over the very long-term following the end of sludge application?" (McBride, 1995). It is not clear if metal availability increases or not with time after ceasing the sludge application, and it is difficult to discern the contribution of metal-retaining organic and inorganic materials of sludge.

Without a conclusion whether the plateau or the time bomb occurs, it is difficult to know the implication of land application of biosolids (Chang et al., 1997). In addition the USEPA 503 does not make any reference about differences in soils and sludge chemistry, and it is assumed that inorganic constituents will permanently retain toxic metals in insoluble forms (McBride, 1995). The soil ability to remove trace elements from the solution determines their phytoavailability (Schmidt, 1997). Physical processes in soils, such as tillage and erosion, may contribute to losses of metals over the long term (McBride et al., 1997). Factors that affect organic matter solubility can modify the solubility and leachability of metals. Many of the sludge used in field experiments by EPA were limestabilized, which means that the $\mathrm{pH}$ was raised. Therefore, the metals had their availability limited by $\mathrm{pH}$, but 
soil $\mathrm{pH}$ can gradually decrease after the cessation of biosolid application (McBride, 1998). If the soil undergoes acidification, the solubility and activity of metals will be further enhanced (Chang et al., 1997; Bolan et al., 2003a).

In this context, conclusions about the risk and advantages of biosolids are still controversial. Moreover, other countries, such as Brazil, follow the USEPA 503. In highly weathered soils, such as Brazilian Oxisols, in which predominates oxides in the clay fraction and $\mathrm{pH}$ is low, metal adsorption reactions are different from those occurring in soils on which the regulation was based.

The dynamics of soil organic matter is also different, when tropical regions are compared to temperate zones. Antoniadis \& Alloway (2001) compared the availability of $\mathrm{Cd}, \mathrm{Ni}$ and $\mathrm{Zn}$ to ryegrass (Lolium perenne $\mathrm{L}$.) at 15 and $25^{\circ} \mathrm{C}$, after applying 10 and $50 \mathrm{tha}^{-1}$ of biosolid on a foamy sand and a clay loam soil. Temperature had a marked effect on metal availability. Both soil extracts and plant samples from the $25^{\circ} \mathrm{C}$ treatment had greater concentrations of $\mathrm{Cd}, \mathrm{Ni}$ and $\mathrm{Zn}$ than those at $15^{\circ} \mathrm{C}$. They concluded that this may be attributed to the organic matter, which decomposed more rapidly at $25^{\circ} \mathrm{C}$. Therefore, predictions assumed in USEPA 503 could not be applied in this specific condition. Regulations for biosolid application should consider the basic physiological phenomena of the biosolid-soil-plant system, and most likely, require regional approach for specific situations.

Whatmuff (2002) conducted an experiment to determine whether guideline soil metal limits from other countries are appropriate for regulating biosolid application under acid soil conditions that occur in New South Wales, UK. Metal uptake by field-grown silverbeet was $>10$-fold higher for $\mathrm{Cd}$ and $>20$-fold higher for $\mathrm{Zn}$ than predicted from the slope of the metal uptake response curve for leafy vegetables used in the USEPA biosolids guidelines. For some treatments, leaf tissue Cd levels exceeded the maximum permissible concentration for $\mathrm{Cd}$ in foodstuffs, and $\mathrm{Zn}$ levels were above phytotoxicity thresholds (with some yield reduction) when silverbeet was grown on soils with $\mathrm{Cd}$ and $\mathrm{Zn}$ concentrations well below soil metal limit concentrations in the United States biosolid guidelines, and equal to levels set in the United Kingdom.

\section{LITERATURE REVIEW}

\section{METALS IN SOILS}

Metals are present in the environment and most of them are essential for animals and plants. They are natural constituents of rocks and sediments. In natural conditions, the main source of trace elements in soils are parent materials. Anthropogenic sources, including industrial emissions and effluents, biosolids, fertilization, soil ameliorants and pesticides can contribute to increasing the amount of metals in soils. In general, it is very difficult to distinguish between the natural metal enhancement and that resulting from anthropogenic sources.

Metals are present in the solid phase and in solution, as free ions, or adsorbed to soil colloidal particles. The heavy metal concentration in topsoil is a result of soil-forming processes, as well as agricultural and human activities. Twelve metals are known to be essential for humans: sodium $(\mathrm{Na})$, magnesium $(\mathrm{Mg})$, potassium $(\mathrm{K})$, calcium $(\mathrm{Ca})$, chromium $(\mathrm{Cr})$, manganese $(\mathrm{Mn})$, iron $(\mathrm{Fe})$, cobalt $(\mathrm{Co})$, copper $(\mathrm{Cu})$, zinc $(\mathrm{Zn})$, selenium $(\mathrm{Se})$ and molybdenum (Mo). Of the nonessential metals, mercury $(\mathrm{Hg})$, lead $(\mathrm{Pb})$, cadmium $(\mathrm{Cd})$, and arsenic (As) are recognized as health hazardous and all have caused major health problems as a result of environmental pollution (Berglund et al., 1984).

The capacity of soils to retain and release metals can be an important factor to predict environmental impact of the use of residues containing these elements. When applied to soils as a solid phase (e.g., biosolids), metals reach the equilibrium with the soil solution and, consequently, with the soil solid-phase. This equilibrium is controlled by chemical properties of soil and the sludge (Figure 1). The kinetics of metal dissolution will determine reaction rates.

To evaluate the potential impact of biosolid application to agricultural land, it is necessary to understand the mobility and bioavailability of heavy metals in the soil. Metal solubility is controlled by adsorption/desorption, precipitation/dissolution and complexation reactions. These interactions influence the partition of metals in the liquid and solid phases, and are responsible for their mobility and bioavailability in the system.

The total heavy metal amount in soils is distributed over some fractions. The soluble and exchangeable fractions are the most important associated to groundwater pollution and to plant nutrition; however, the movement of metals in sludge-amended soils depends on the composition of the sludge (Sastre et al., 2001). For example, biosolid with high iron oxide content can reduce the risk of pollution by heavy metals. Ohtani et al. (2001) investigated the effect of artificial precipitation (solutions of $\mathrm{HNO}_{3}, \mathrm{H}_{2} \mathrm{SO}_{4}$, and $\mathrm{HCl}$, prepared to $\mathrm{pH} 4.5$ ) on the uptake of heavy metals by Brassica rapa from non-con-

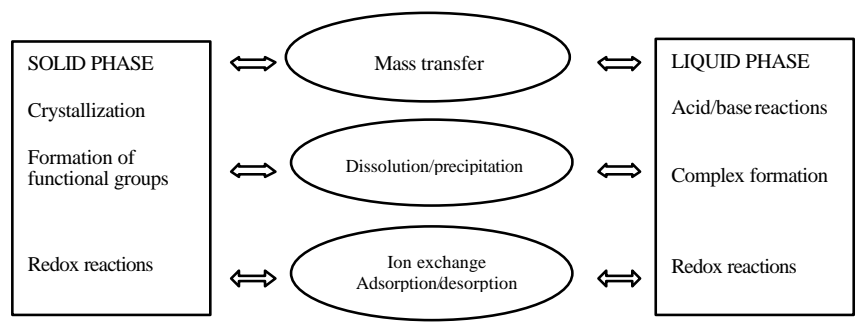

Figure 1 - Types of interactions within and between solid and solution phases in soil systems (Mattigod \& Page, 1983). 
taminated, Cd-contaminated, and biosolid compost (BC)amended sandy soil. They observed that all acid treatments increased the $\mathrm{Cd}$ concentration in shoots grown on Cd-contaminated soil, but only $\mathrm{HNO}_{3}$ precipitation increased it in BC-amended soil. Marked changes in soil $\mathrm{pH}$ were not observed, raising the possibility that $\mathrm{Cd}$ uptake by $B$. rapa depends on the anions and the chemical forms of $\mathrm{Cd}$ in the soil under conditions of heavy metal enrichment.

The extractability of metals can be reduced after many years of sludge addition, and this behavior may result from the increase in soil organic matter content (Karapanagiotis, 1991). The mobility and bioavailability of metals are related to their solubility of their geochemical form. Olajire et al. (2003) studied four contaminated soils of Southern Nigeria, and found that the apparent mobility and potential bioavailability of some metals in the soil were: $\mathrm{Pb}>\mathrm{Zn}>\mathrm{Cu}>\mathrm{Ni}>\mathrm{Cd}$.

\section{ADSORPTION REACTIONS}

Adsorption, defined as the accumulation of a substance or material at an interface between the solid surface and the bathing solution, seems to be the most important chemical process controlling the behavior and bioavailability of metals in soils (Alloway, 1990; Sparks, 1995). These reactions are important not only for the control of the activity of heavy metals in soil solution, but also in natural water bodies (McBride et al., 1997; Salam $\&$ Helmke, 1998). The metal-complexing groups exposed on the solid surface in soils include the hydroxyl groups that protrude from the edge surfaces of layer silicates and from the surface of metal oxides, the ditrigonal cavities in the basal planes of clay minerals and carboxyl, amine and phenolic hydroxyl groups that reside on the surfaces of the soil organic matter (Sposito, 1983).

As consequence of adsorption, metals are removed from de soil solution and retained on the colloidal soil surface. Many mechanisms are involved in metal adsorption, including cation exchange or non-specific adsorption and specific adsorption. Physical (van der Waals and electrostatic ion exchange) and chemical (inner-sphere complexation) forces are involved in the adsorption of metals in soils (Sparks, 1995). The nature of the interactions and the mechanisms of adsorption can be different, as proposed by Filep (1999):
a) van der Waals
b) Hydrogen bonding
Molecular adsorption
c) Ion-dipole interaction
d) Electrostatic forces
(physical adsorption)
e) Coordinative and other types of chemical bonding
Ion exchange
Chemisorption

The type of interaction which will be predominant depends on the quantity and characteristics of the sites of the solid phase, the concentration of metals and of all ligands capable of forming organomineral complexes and on soil $\mathrm{pH}, \mathrm{EC}$ and redox potential (Kiekens, 1983). The adsorption-free energy at the surface of adsorbents $\Delta \mathrm{G}_{\text {adsorption }}$ may be described as (1) (Ji \& Li, 1997):

$\Delta \mathrm{G}_{\text {adsorption }}=\Delta \mathrm{G}_{\text {coulomb }}+\Delta \mathrm{G}_{\text {chem.. }}+\Delta \mathrm{G}_{\text {reaction }}$

where $\Delta \mathrm{G}_{\text {coulomb }}$ is the free energy caused by electrostatic interaction and is related to the electric charge of ions; $\Delta \mathrm{G}_{\text {chem. }}$, is the free energy referring to the specific adsorption, the bounding forces being determined by the nature of the adsorbent and of the ion species; and $\Delta \mathrm{G}_{\text {reaction }}$ depends on the size and polarizability of the adsorbed ions, and of the structure of the solution adjacent to the adsorbent surface. If $\Delta \mathrm{G}_{\text {chem }}$ is high, ions with the same charge of the surface can be adsorbed, since this free energy component can overcome the electrostatic repulsive force (Ji \& Li, 1997). Silveira et al. (1999) and Dias et al. (2003), studying, respectively $\mathrm{Cu}$ and $\mathrm{Cd}$ adsorptions to positively charged samples of subsurface soil, observed that the free energy for metal adsorption decreased with an increase in the amount of the added metal. These authors showed also that the free energy values were negative for all metal concentrations, which means that the reactions were spontaneous. Probably, in this situation, the $\Delta \mathrm{G}_{\text {chem }}$ for $\mathrm{Cu}$ and $\mathrm{Cd}$ were high enough to overcome repulsive forces between the positive charges in the colloid surface, and that of the metal.

\section{Non-specific adsorption}

In non-specific adsorption, also known as cation exchange, metals are bound by electrostatic forces resulting in the formation of outer-sphere complexes. The ions in soil solution, such as heavy metals, are in equilibrium with counter-ions that balance the surface charge of the colloids. According to the principle of electroneutrality, the non-specific adsorption of metals should be followed by desorption of stoichiometric quantities of counter-ions (Harmsen \& Vlek, 1985; Ji \& Hi, 1997). Non-specific adsorption is a reversible, diffusion-controlled, stoichiometric process, and there is some selectivity or preference of ions by the adsorbent, depending of their valence and degree of hydration. Both organic and inorganic colloids are involved in electrostatic adsorption.

The non-specific adsorption of cations is directly controlled by negative charge, but not necessarily by the net surface charge of the soil. For instance, Oxisols, which may have positive net charge in the B horizons, can still adsorb metals when the $\mathrm{pH}$ is below their isoelectric point of charge (Silveira et al., 1999; Dias et al. 2001a). Bolan et al. (2003b) studied the effect of increasing $\mathrm{pH}$ on the 
adsorption of $\mathrm{Cd}$ in two soils which varied in their variable-charge components, and observed that since there was no direct evidence for $\mathrm{CdCO}_{3}$ or $\mathrm{Cd}(\mathrm{OH})_{2}$ precipitation in the variable charge soil used for the plant growth experiment, alleviation of phytotoxicity could be attributed primarily to immobilization of $\mathrm{Cd}$ by enhanced, $\mathrm{pH}$ induced increase in negative charge.

The affinity of soil colloid surfaces for cations increases as the valence increases. For cations of different valences, the affinity should generally follow the order $\mathrm{M}^{+}<\mathrm{M}^{2+}<\mathrm{M}^{3+}$. For cations of the same valence, the adsorption strength should be determined mainly by the hydrated radius of the ions ( $\mathrm{Ji} \& \mathrm{Li}, 1997)$. Gomes et al. (2001) observed that in a competitive situation $\mathrm{Cr}, \mathrm{Pb}$, and $\mathrm{Cu}$ were the heavy-metal cations most strongly adsorbed by seven Brazilian soils, whereas $\mathrm{Cd}, \mathrm{Ni}$, and $\mathrm{Zn}$ were the least adsorbed. For metals of the same valence, the authors observed that sequences did not exactly follow the order of electronegativity.

Surface charge, $\mathrm{pH}$ and the concentration of ions, as well as of its accompanying anions, can affect electrostatic adsorption of metals. Soil pH can affect metal speciation in solution and also the surface charge in variable charge soils (Ji \& Li, 1997). Yoo \& James (2002) evaluated the extractability of added $\mathrm{Zn}$ in a laboratory study using sequential extractions as a function of $\mathrm{pH}$ and biosolid additions in $\mathrm{A}$ and $\mathrm{B}$ horizon samples of Psammentic Hapludult, Typic Hapludult, and Typic Endoaquult. They stated that the addition of biosolid, compared to no biosolid addition, lowered the exchangeability of $\mathrm{Zn}$ and favored the partitioning into nonexchangeable $\mathrm{Zn}$ forms at $\mathrm{pH}>5.8$ in all soils, and concluded that $\mathrm{pH}$ was a controlling variable for the redistribution of water-soluble, exchangeable and nonexchangeable $\mathrm{Zn}$, affected by biosolid addition.

The effect of accompanying anions is more marked in variable charge soils, as they can alter the ionic strength of the soil solution, and thus the surface charge, and also form ion pairs with metals. Although in some cases the contribution of electrostatic reactions for metal retention in soils can be neglected, this mechanism is important to supply nutrients to soil solution and, consequently, to plants. The presence of lactate and citrate increases the solubility of $\mathrm{Cu}$ and $\mathrm{Cd}$, and treatment with these acids in some cases affect the distribution of their chemical forms (Ahumada et al., 2001). Acetate incorporation increased the amount of $\mathrm{Cu}$ associated to organic matter, and the presence of citrate affected the fractions of exchangeable $\mathrm{Cu}$, carbonate, and associated manganese oxides.

\section{Specific adsorption}

The adsorption of metals by soils - specific adsorption - can involve specific forces. Specific adsorption of ions on colloid surfaces results in the formation of stable molecules, with high bound energy, also called inner-sphere complexes (Sparks, 1995). This mechanism of metal binding is often not reversible, slower than outersphere complexation, and is weakly affected by the ionic strength of soil solution (Sparks, 1995). After some time, the tendency is that metals specifically adsorbed by the surface of colloids diffuse to the interior of particles, hindering subsequent desorption (Barrow, 1985). Organic matter amendments added to metal-contaminated soil can have ameliorative effects resulting from increases in surface area and in the number of specific adsorption sites (Shuman et al., 2002).

In oxidic soils, metal adsorption can not be explained simply by electrostatic forces. The zero point of charge of most metal oxides lies above $\mathrm{pH} 8$, and the adsorption of transition metal ions occurs frequently at $\mathrm{pH}$ 3-7 (Yu et al., 1997). In this case, the surface has a positive net charge, and the repulsion forces between the colloid surface and the metals can occur; metals combine with the oxygen and hydroxyl groups on the oxide surface, forming surface complexes.

The hydrous oxides of $\mathrm{Al}, \mathrm{Fe}$, and $\mathrm{Mn}$ and the organic matter are the main soil constituents involved in specific adsorption. Some layer silicates can have the ability of specific adsorption of heavy metals, being in this way similar in properties to the hydroxyl groups on oxide surfaces. Most of the cations that can be adsorbed specifically by soils, such as $\mathrm{Cu}, \mathrm{Zn}, \mathrm{Co}$, and $\mathrm{Cd}$, are heavy metals. This pattern occurs because heavy metals and metal ions of the IB group and II group have large amounts of electric charge in the atomic nucleus, small ionic size and great polarizability (Yu et al., 1997). Therefore, the ability of heavy metals for deformation is greater than that of alkaline metals and alkaline earth metals. Besides, heavy metals might exist as hydrated cations such as $\mathrm{MOH}^{+}$, which in turn contribute to the decrease in the average amount of electric charge per ion, and to the decrease in the energy barrier that must be overcome when ions approach the oxide surface, facilitating the interactions between ions and the colloid surface ( $\mathrm{Yu}$ et al., 1997).

The surface properties of oxides are modified in response to metal adsorption. The metal adsorption does not result in desorption of counter-ions and, thus, the net of surface charges can be altered (2).

$-\mathrm{Fe}-\mathrm{OH}+\mathrm{M}\left(\mathrm{H}_{2} \mathrm{O}\right)_{6}{ }^{2+} \rightarrow-\mathrm{Fe}-\mathrm{OM}\left(\mathrm{H}_{2} \mathrm{O}\right)_{5}^{+}+\mathrm{H}_{3} \mathrm{O}^{+}$

$\mathrm{M}=$ metal.

\section{ADSORPTION ISOTHERMS}

Heavy metal adsorption in soils can be described by many isotherms, describing the relationship between the metal concentration in the equilibrium solution and the amount adsorbed in the solid phase. The Langmuir equation, developed to describe the adsorption of gas 
molecules on planar surfaces, can be expressed as (3):

$$
\mathrm{M}_{\mathrm{ads}}=\frac{\mathrm{K} \cdot \mathrm{C} \cdot \mathrm{b}}{1+\mathrm{K} \cdot \mathrm{C}}
$$

where $\mathrm{M}_{\text {ads }}$ is the amount of $\mathrm{M}$ adsorbed per unit of adsorbate; $\mathrm{K}$ is a constant related to the bonding energy; $\mathrm{C}$ is the activity of the ion; and $\mathrm{b}$ is the maximum amount of ions that will be adsorbed by a given sorbate. The Langmuir equation best describes sorption at low sorptive concentrations. Because of its original assumptions, this model is not valid in heterogeneous surfaces, such as soils, and it should only be used for qualitative and descriptive purposes (Sparks, 1995).

The Freundlich equation (4) was initially developed to describe gas phase adsorption and solute adsorption:

$\mathrm{x}=\mathrm{k} \mathrm{C}^{\mathrm{n}}$ or $\log \mathrm{x}=\log \mathrm{k}+\mathrm{n} \log \mathrm{C}$

where $\mathrm{x}$ is the amount of ion adsorbed per unit of adsorbent at concentration $\mathrm{C}$ of adsorbate, and $\mathrm{k}$ and $\mathrm{n}$ are regression parameters. The Freundlich adsorption isotherm is an empirical model and its major disadvantage is that it does not include an adsorption maximum as Langmuir. The equation is primarily applicable at low to medium concentrations, or at higher temperatures (Filep, 1999)

Burton et al. (2003) used isotherm equations to estimate biosolid-derived $\mathrm{Cu}$ and $\mathrm{Zn}$ loadings to soil in order to result in an "allowable" output concentration from the soil solution to the surrounding environment. According to the authors, for sludge loading estimates based on soil sorption characteristics to be relevant to environmental protection, the sorption depressing effect of dissolved organo-metallic complexes should be quantitatively considered.

The Langmuir and Freundlich isotherms can be easily determined in laboratory experiments, but neither provides much information on the mechanism involved, since both equations are capable of describing data, irrespective of the actual retention mechanism, assuming uniform distribution of adsorption sites and the absence of any reactions between adsorbed ions (Alloway, 1990). Adsorption isotherms can be considered descriptions of macroscopic data and do not define a reaction mechanism (Sparks, 1995). In spite of their disadvantages, those isotherms have been used in many adsorption studies. In Oxisol, for instance $\mathrm{Cu}$ and $\mathrm{Cd}$ adsorption can be described either by Langmuir or by Freundlich isotherms (Dias et al., 2001b; Silveira et al., 2002). The same conclusion was found by Mesquita et al. (2002) studying $\mathrm{Cu}$ and $\mathrm{Zn}$ adsorption in Gleyic Podzol.

The adsorption reactions for most of the heavy metals are irreversible and the hysteresis (the different path followed by the adsorption and the desorption isotherms) seems to be greater for $\mathrm{Cu}$ and $\mathrm{Pb}$ than for $\mathrm{Zn}$
(Berglund et al., 1984). The following parameters are pointed by Berglund et al. (1984) to explain the selective adsorption of trace elements and the occurrence of hysteresis:

a) properties of the metal ion, such as ionic radius, po larizability, thickness of the hydration shell, equivalent conductance, hydration enthalpy and entropy;

b) number of $\mathrm{pH}$-dependent adsorption sites;

c) steric factors;

d) formation of hydroxy complexes;

e) affinity of the ions to form organomineral complexes and their stability;

f) interaction with amorphous hydroxides.

Adsorption isotherms can be classified in four general types: S, L, H and C (Sparks, 1995). The S-type isotherm shows an initial increasing with adsorptive concentration, but eventually decreases and becomes zero as vacant adsorbed sites are filled. The L-type or Langmuir isotherm describes a decreasing slope as concentration increases; this behavior is indicative that the adsorption sites have higher affinity for the adsorptive at low concentrations. The $\mathrm{H}$-shaped or high affinity isotherm is characterized by the strong adsorbate-adsorptive interaction, such as inner-sphere complexes. The C-type isotherm, which is approximately linear, follows the Freundlich model with an exponent (n) equal to 1 . This kind of isotherm indicates that the adsorption of ions or molecules is not dependent of any bonding between the adsorbent and adsorbate.

\section{PARTITIONING COEFFICIENT}

The partitioning coefficient or distribution coefficient $\left(\mathrm{K}_{\mathrm{d}}\right)$ is used to compare the behavior of contaminants in different soils. The $K_{d}$ provides a measure of the ratio of the amount of a material that is adsorbed and the amount that is in solution, and can be represented as (5):

$\mathrm{K}_{\mathrm{d}}=\frac{\left[\mathrm{M}_{\text {Soil }}\right]}{\left[\mathrm{M}_{\text {Solution }}\right]}$

The distribution coefficient is an useful parameter for comparing the sorptive capacities of different soils or materials for any particular ion, when measured under the same experimental conditions (Alloway, 1990). The adsorption of heavy metals in soils is a competitive process between metals in solution and those adsorbed to soil particles.

In the solid phase, metals can be bound mainly to organic matter and onto iron and manganese oxide surfaces (Impellitteri et al., 2001), but these adsorbents have different selectivity for metals. The attributes of the surface adsorbent or the soil type and the characteristics of the metal noticeably affect the distribution coefficient. In this case, the $K_{d}$ can be used to indicate the affinity of 
the solid phase for specific metals. In a competitive sorption experiment, Veeresh et al. (2003) observed that the affinity of metals, based on their Kd values, was $\mathrm{Pb}>\mathrm{Cu}$ $>\mathrm{Zn}>\mathrm{Ni}$ or $\mathrm{Cd}$. When metals are introduced to the system as biosolids, only a small fraction of these elements is released to the solution (Hyun et al., 1998; Vulkan et al., 2002). This pattern occurs because of the high adsorptive affinity of metals to the biosolid's matrix. McBride et al. (2000) obtained $\mathrm{K}_{\mathrm{d}}$ values for $\mathrm{Cu}, \mathrm{Zn}$ and Cd close to 104 for sludge-treated calcareous soils with the highest organic matter content, indicating a strong metal retention that may be attributed to binding by organic matter, but free calcium carbonate in the soil was probably important in limiting metal lability and solubility. In 64 field-collected, contaminated soils samples, containing between 0.1 and $38 \mathrm{mg} \mathrm{Cd} \mathrm{kg}^{-1}$, Sauve et al. (2000) found $\mathrm{K}_{\mathrm{d}}$ values varying over from 10 to 100,000 , and the fraction of the dissolved $\mathrm{Cd}$ present in solution as the estimated free $\mathrm{Cd}^{2+}$ species, varied between 0 and $60 \%$, but averaged about $20 \%$.

\section{FACTORS AFFECTING METAL ADSORPTION}

Mineral and organic soils can bind metals to different extents. Organic matter, $\mathrm{Fe}$ and $\mathrm{Al}$ hydrous oxides, and clay content are the most significant soil properties influencing sorption reactions (Barry et al., 1995, Bolan $\&$ Duraisamy, 2003). Even if these active components are not present at high concentrations in the soil, they may be dispersed on the surface of sand and clay minerals, thus exerting considerable control upon adsorption reactions. The complex formed at the surface at higher metal loadings, can either be distribute evenly over the surface or form clusters (Martinéz \& McBride, 1998). Metals such as $\mathrm{Cd}^{2+}, \mathrm{Cu}^{2+}, \mathrm{Pb}^{2+}$, and $\mathrm{Zn}^{2+}$ can be imprisioned within iron oxide structures under specific conditions, either by forming a true solid solution as clusters with the oxides, or by segregating within the oxide or at the oxide surface (Martinéz \& McBride, 1998).

Additionally, soil $\mathrm{pH}$, cation exchange capacity (CEC) and redox potential can also regulate the mobility of metals in soils (Lombi \& Gerzabek, 1998). Soil pH, for instance, is very important for most heavy metals, since metal availability is relatively low when $\mathrm{pH}$ is around 6.5 to 7 . With the exception of Mo, Se, and As, the mobility of trace elements is reduced with increasing soil $\mathrm{pH}$ because of the precipitation as insoluble hydroxides, carbonates, and organic complexes. At high $\mathrm{pHs}$, ion hydrolysis $\left(\mathrm{MOH}^{+}\right)$is favored, and the energy barrier that must be overcome when these ions approach the surface of soil particles is decreased (Yu et al., 1997). The CEC is directly related to the soils capacity of adsorbing heavy metals. The greater the CEC values, the more exchange sites on soil minerals will be available for metal retention. Surface and subsurface samples of the same soil can exhibit different capacities to adsorb heavy metals, since the adsorption behavior depends of the combination of the soil properties and the way they affect each specific element (Barry et al., 1995).

The presence of competitive cations can affect metal adsorption in soils. For instance, $\mathrm{Ca}^{2+}$ competes effectively with cationic heavy metals for adsorption sites, and this competition seemed to be greater for $\mathrm{Zn}$ and $\mathrm{Cd}$ than for $\mathrm{Cu}$ and $\mathrm{Pb}$ (Kiekens, 1983; Pierangeli et al., 2001; 2003). This occurs because $\mathrm{Zn}$ and $\mathrm{Cd}$ are basically retained in the soil by exchange reactions, while $\mathrm{Cu}$ and $\mathrm{Pb}$ form inner-sphere complexes with organic matter and with $\mathrm{Fe}, \mathrm{Al}$, and $\mathrm{Mn}$ oxides. The presence of inorganic and organic ligands in the soil solution can affect the adsorption of trace metals. These effects can be classified into three general categories (Sposito, 1983):

(i) The ligand has high affinity for the metal and they form a soluble complex with high affinity for the adsorbent.

(ii) The ligand has high affinity for the adsorbent, is adsorbed, and the adsorbed-ligand has a high affinity for the metal.

(iii) The ligand has high affinity for the metal and they form a soluble complex with low affinity for the adsorbent.

Soil redox potential can influence the solubility of heavy metals. In conditions where oxidation reactions are involved, the solubility of heavy metals increases with decreasing $\mathrm{pH}$. But, in reducing conditions, the solubility of $\mathrm{Zn}, \mathrm{Cu}, \mathrm{Cd}$, and $\mathrm{Pb}$ is higher in alkaline $\mathrm{pHs}$, as a result of the formation of stable soluble organomineral complexes. On the other hand, if $\mathrm{pH}$ ranges between 4 and 6 , the solubility of these metals will be lower because of the formation of insoluble sulfides or insoluble organomineral complexes (Kiekens, 1983).

\section{Organic matter}

Soil organic matter $(\mathrm{OM})$ is quite effective in retaining metals. Metal-organic associations can occur both in solution and in the solid surfaces of either native soil constituents or any added material (e.g., biosolids). In a heavy metal-polluted forest soil, Kiikkila at al. (2002) studied the effect of biosolids as organic immobilizing agents and observed that exchangeable $\mathrm{Cu}$ concentration decreased. On the other hand, the metal could be complexed by dissolved organic matter (DOC), which act enhancing leaching in the field (Moolenaar \& Beltrami, 1998).

Schaecke et al. (2002) evaluated biosolid application rates (equivalent $82-330 \mathrm{t} \mathrm{ha}^{-1}$ dry matter) incorporated in 0-0.25 $\mathrm{m}$ depth of a Chernozem (1982-1985). The aim of the investigation was to study the fate of heavy metals $\mathrm{Zn}, \mathrm{Cd}, \mathrm{Cu}, \mathrm{Ni}, \mathrm{Pb}$, and $\mathrm{Cr}$, and to determine their concentration in the soil fractions. Eleven years 
after the last application, metals supplied with the sludge had moved as far as $50 \mathrm{~cm}$ in depth. Concentrations of $\mathrm{Zn}, \mathrm{Cd}, \mathrm{Cu}, \mathrm{Ni}$, and $\mathrm{Cr}$ in the saturation extract of the sampled soil layers were closely correlated to concentrations of dissolved organic carbon (DOC), that is, the heavy metal displacement was partly linked to the DOC movement in the soil.

Humus and other organic compounds can chelate metals and form stable complexes. Humic fractions with lower molecular weights are more effective for complexation with metallic ions, since they contain phenolic $(\mathrm{Ph}-$ $\mathrm{OH})$ and carboxylic $(-\mathrm{COOH})$ groups in higher concentrations.

Humic substances may be classified according to their solubility. Humic acids (HA) are soluble only in alkaline media, while fulvic acids (FA) are soluble in alkaline and acid media. Both HA and FA play different roles in controlling plant uptake. Generally, FAmetal complexes are soluble, while HA-metal complexes are insoluble (McBride, 1995). Depending on the complex solubility, metal-OM complexes can be found either in the liquid or in the solid phase. In general, FA form soluble complexes with metals over a wide range of $\mathrm{pH}$. In soluble complexes, metals can be available to plant uptake, while in solid complexes they are immobilized. With time, the tendency is that soluble organic compounds and organic decomposition decrease, total dissolved metals stabilize at lower values and bioavailability diminishes (McBride, 1995), while soluble complexes change to insoluble ones in soil solution (Schmidt, 1997).

The high degree of selectivity shown by organic matter for certain metals suggests that they coordinate directly, forming inner-sphere complexes with the acid functional groups (McBride, 1989). The stability of organo-complexes is strongly influenced by the $\mathrm{pH}$ range. Generally at low $\mathrm{pH}$, most metals are in the cationic form, but as $\mathrm{pH}$ increases, humate complexes are formed. For FA, the complex stability increases from $\mathrm{pH} 3.5$ to 5.0 (Kiekens, 1983). The stability constant of metal-FA complexes may decrease with increasing ionic strength in the solution. Even tough stability constants for metals with either FA or HA can be difficult to be determined, many estimates have been carried out (Table 1).
An anthropogenic fulvic acid, such as that extracted from a composted sewage, has macroscopic complexation properties (magnitude of the conditional stability constant and binding sites concentration) somewhat similar to the natural FA samples, but has some binding site structures containing nitrogen that probably play important role in the complexation, besides oxygen containing structures (Silva \& Oliveira, 2002).

McBride (1989) suggested the following sequence of affinity of divalent metal ions for organic matter: $\mathrm{Cu}>\mathrm{Ni}>\mathrm{Pb}>\mathrm{Co}>\mathrm{Ca}>\mathrm{Zn}>\mathrm{Mn}>\mathrm{Mg}$. In general, the more electronegative the metal ion, the stronger the bond formed with organic matter. Copper is commonly found strongly complexed by organic matter. Evidences from electron paramagnetic resonance (ESR) studies suggested that $\mathrm{Cu}^{2+}$ is bonded rigidly as a inner-sphere complex, and that at high metal concentrations, the complex may be mobile (McBride, 1989). This metal may be bound by $\mathrm{HA}$, coordinating either with $\mathrm{O}$ atoms or with $\mathrm{N}$ atoms, and the first complex would be more accessible for plant uptake (Martin Neto et al., 1991). Most of the first-row transition metals $\left(\mathrm{Mn}^{2+}, \mathrm{Fe}^{2+}, \mathrm{Co}^{2+}\right)$ and alkaline earth metals $\left(\mathrm{Ca}^{2+}, \mathrm{Mg}^{2+}\right)$ form outer-sphere complexes with organic matter. Desorption of heavy metals from organic matter requires a large activation energy to be overcome (McBride, 1989).

The influence of $\mathrm{pH}$ on humified substances occurs because their functional groups, such as carboxyl, phenolic and amino, are $\mathrm{pH}$-dependent. If the $\mathrm{pH}$ of the soil solution changes, the protonation or deprotonation of the charged surface will occur. For carboxyl groups, the pK is about 3-5, while for the phenolic, is between 9-10 (Filep, 1999). Therefore, the ionization capacity is higher for carboxyl groups than for phenolic groups at the $\mathrm{pH}$ values commonly found in soils.

Organic matter can form organomineral complexes with 2:1 type clay minerals and with $\mathrm{Fe}$ and $\mathrm{Al}$ oxides. These complexes have strong coordination bonding and alter the colloid characteristics. The interaction of hydrous oxide with organic matter also appears when a clay mineral surface is covered by a Fe or Al-hydroxide film (Filep, 1999).

Table 1 - Stability sequence of metals for fulvic and humic acids as a function of pH. (Adapted from Filep, 1999)

\begin{tabular}{lcl}
\hline Fraction & $\mathrm{pH}$ & \multicolumn{1}{c}{ Stability Sequence } \\
\hline Fulvic Acid & 3 & $\mathrm{Fe}^{3+}>\mathrm{Al}^{3+}>\mathrm{Cu}^{2+}>\mathrm{Ca}^{2+}>\mathrm{Zn}^{2+}>\mathrm{Mn}^{2+}>\mathrm{Mg}^{2+}$ \\
& 5 & $\mathrm{Cu}^{2+} \approx \mathrm{Ca}^{2+}>\mathrm{Mn}^{2+}>\mathrm{Zn}^{2+}>\mathrm{Mg}^{2+}$ \\
& 7 & $\mathrm{Cu}^{2+}>\mathrm{Ca}^{2+}>\mathrm{Zn}^{2+}>\mathrm{Mn}^{2+}$ \\
Humic Acid & 8 & $\mathrm{Cu}^{2+}>\mathrm{Ca}^{2+}>\mathrm{Zn}^{2+}>\mathrm{Mn}^{2+}$ \\
& 7 & $\mathrm{AP}^{3+}>\mathrm{Cu}^{2+}>\mathrm{Ca}^{2+}>\mathrm{Mn}^{2+}>\mathrm{Zn}^{2+}$
\end{tabular}




\section{Iron oxides}

Iron oxides (a term thereafter used for oxides and oxyhydroxides of $\mathrm{Fe}$ ) play an important role in adsorption reactions, particularly when the equilibrium between the solid-solution interface is shifted towards the solid. Iron oxides are present in almost all soils, and even at low concentrations, they influence soil color, soil structure and ion adsorption. Almost all rocks contain at least some iron (Cornell \& Schwertmann, 1996).

In soils, the mineral species, concentration and crystal properties of the iron oxide vary greatly. The most frequent and stable iron oxides in soils are goethite (a$\mathrm{FeOOH})$ and hematite $\left(\mathrm{a}-\mathrm{Fe}_{2} \mathrm{O}_{3}\right)$. Goethite and hematite are important constituents of the highly weathered soils of tropical and subtropical regions that contain kaolinite as the major clay mineral (Singh \& Gilkes, 1992). These minerals can play important roles in chemical and physical attributes of Oxisols, such as aggregate stability and particle dispersion (Alleoni \& Camargo, 1994a; 1994b; 1995; Pinheiro-Dick \& Schwertmann, 1996).

Lepidocrocite, ferrihydrite and maghemite, although less common, may also be present in soils (Schwertmann, 1991). Ferrihydrite is a poorly ordered oxide and may act as a very efficient sink for trace elements because of its high specific surface area.

Generally, iron oxide solubilities are very low at the $\mathrm{pH}$ range of soils, and depends on the particle size, crystallinity and the percent of Al substitution (Schwertmann, 1991). The quantification in soils and sediments is often complicated by a considerable variation in crystallinity (Schwertmann et al., 1985), but it is estimated that iron oxides concentrations in various soils vary from $<0.1$ to $>50 \%$ and they may be evenly distributed in the matrix or concentrated in horizons, concretions, mottles, bands (Schwertmann, 1991) or clay mineral coatings. They may be present in soils as amorphous iron oxides, which is the most chemically active portion and also important for geochemistry studies (Chao \& Zhou, 1983). The ratio between amorphous iron oxides and the total free ion has been used as an index for soil genesis and classification. When the ratio between free and total ion approaches 1 (one), it is an indication of the maturity of a soil (Cornell \& Schwertmann, 1996).

The oxide surface charge is $\mathrm{pH}$-dependant, determined by the $\mathrm{H}^{+}$and $\mathrm{OH}$ concentrations in solution. Iron oxides are considered to be the main material in producing positive surface charge in variable charge soils because their $\mathrm{Fe}-\mathrm{OH}$ groups can absorb $\mathrm{H}^{+}$from he solution when the $\mathrm{pH}$ is lower than the zero point of charge (Zhang \& Zhao, 1997). The association of iron oxides with clay minerals may affect the soil negative surface charge. Silveira et al. (2002) studied $\mathrm{Cu}$ adsorption in surface (0-0.2 m) and subsurface samples of a heavy-clayeytextured Anionic Acrudox, a medium-textured Anionic "Xanthic" Acrudox and a Rhodic Hapludalf, before and after the removal of organic matter and/or iron oxides. When soil $\mathrm{pH}$ was below the zero point of salt effect (ZPSE), the removal of iron oxides increased the retention of copper, more likely because of a reduction in the repulsion forces between the positively charged surface and the metal. For $\mathrm{pH}$ values above the ZPSE, oxides effectively contributed for $\mathrm{Cu}$ adsorption, since their removal was followed by a decreasing of the soil capacity to retain copper.

Iron oxides can markedly affect heavy metal retention, mobility, and bioavailability. Cajuste et al. (2000) found the greatest amounts of $\mathrm{Zn}$ and $\mathrm{Cu}$ in the nonresidual fraction associated to the $\mathrm{Fe}-\mathrm{Mn}$ oxide fraction, and Sastre et al. (2001) observed Ni bound to Fe and $\mathrm{Mn}$ oxides. In many soils, $\mathrm{Fe}$ oxides determine the availability to plants of both native and applied plant nutrients (Singh \& Gilkes, 1992). Some heavy metals can react with the oxide surface, penetrating the coordination shell of the $\mathrm{Fe}$ atom, exchanging their $\mathrm{OH}$ and $\mathrm{OH}_{2}$ ligands and forming covalent bonds (Schwertmann \& Taylor, 1977). This specific sorption or chemisorption is influenced by $\mathrm{pH}$ and ion concentration.

Heavy metal adsorption on iron oxides is generally accompanied by the release of protons, and the extent of the adsorption is strongly $\mathrm{pH}$ dependent (Cornell \& Schwertmann, 1996). Initially, metals are sorbed to the iron oxide surface sites at the solid-water interface, but they may diffuse to internal sorption sites, which are not readily accessible by the bulk solution (Ford et al., 1997). Some heavy metals, such as $\mathrm{Cd}, \mathrm{Cu}$, and $\mathrm{Zn}$, can be present as constituents of the iron oxide structure (KabataPendias \& Pendias, 1984; Singh \& Gilkes, 1992).

\section{SOLID AND LIQUID PHASE EQUILIBRIUM}

The total contents of heavy metals in soil-sludge mixtures may not reflect their bioavailability. Higher contents of heavy metals in the soil do not always mean higher plant contents. For some authors, the total metal concentration is the most useful index to assess the degree of metal accumulation in a soil, but metal bioavailability is better reflected by soil solution composition (Mattigod \& Page, 1983). Lópes-Mosquera et al. (2000) did not find significant correlation between the total metal concentrations in the soil and plant tissues. Although metal solubility is initially reduced by sorption reactions, long-term solubility is controlled by chemical forms, which could vary with time (Martinéz \& McBride, 1998). Knowledge of metal distribution and speciation in solution is essential for understanding soil-metal chemistry (Mattigod \& Page, 1983).

Metals in solution can occur as free-ions (hydrated) or interact with other ions or molecules forming ion pairs. Natural ecosystems contain an unidentified number of ligands in different concentrations (Vulkan et al., 2002). In soil solution, around 100 to 200 different 
soluble complexes can be found (Sposito, 1994). Generally, free metal cations and sulfate complexes are more important in acid soils, while carbonate and borate complexes are predominant in alkaline environments (Sposito, 1983). The species present in solution can be exemplified as described in Table 2.

In sludge-amended soils, the metal distribution depends on a wide range of characteristics of the soil and the sludge, of which $\mathrm{pH}$ is probably the most important (Obrador et al., 1997). Electrostatic attraction and covalent donor-acceptor reactions are involved in the formation of ion pairs. To form ion pairs, the oppositely charged ions should get closer to each other than the usual average distance. The necessary distance for the formation of ion pairs $\left(\mathrm{r}_{\min }\right)$ can be calculated according to equation 6 :

$r_{\min }=\frac{\left(Z_{i} \cdot Z_{j}\right) \cdot e^{2}}{8 \pi \varepsilon K T}$

where $\mathrm{Z}_{\mathrm{j}}$ is the charge of chosen ion $\mathrm{j}$; $\mathrm{Z}_{\mathrm{i}}$ is the charge of ion $I$ adjacent to ion $\mathrm{j}$; $\underline{e}$ is the unit of electric charge; e is the permittivity of the medium; $\mathrm{k}$ is the Boltzmann constant; and $\mathrm{T}$ is the thermodynamic temperature.

If $r_{\min }$ is reached, ion pairs can be formed in soil solution. For instance, in solutions of type $1: 1$, at $25^{\circ} \mathrm{C}$, the distance for ion pair formation is $0.357 \mathrm{~nm}$, while for solutions of type 2:2 it is approximately $1.4 \mathrm{~nm}$ (Filep, 1999). The ionic strength of the solution affects the types of ion pairs, i.e., in more concentrated solutions of strong electrolytes, ions can form ion pairs easier than in diluted solutions.

Carbonates, phosphates, molybdates, $\mathrm{OH}$, and several other organic compounds, including humates and fulvates $(\mathrm{R})$ can precipitate with metals. The precipitation of free ions $\left(\mathrm{M}^{\mathrm{n}+}\right)$ in soil solution depends on the solubility product Ks (7).

$-\log \left(M^{\mathrm{n}+}\right)=\mathrm{pM}=\frac{\mathrm{pKs}-\mathrm{m} \cdot \mathrm{pR}}{\mathrm{n}}$
Based on the product of solubility, Lindsay (1979) described theoretical equations for metals as follows:

$$
\begin{aligned}
& \log \left(\mathrm{Al}^{3+}\right)=8.04-3 \mathrm{pH} \\
& \log \left(\mathrm{Fe}^{3+}\right)=2.7-3 \mathrm{pH} \\
& \log \left(\mathrm{Zn}^{2+}\right)=5.8-2 \mathrm{pH} \\
& \log \left(\mathrm{Cu}^{2+}\right)=2.8-2 \mathrm{pH} \\
& \log \left(\mathrm{MoO}_{4}^{2-}\right)=2 \mathrm{pH}-20.5
\end{aligned}
$$

In all these cases, the solubility of $\mathrm{M}$ is dependent on $\mathrm{pH}$ (Kiekens, 1983). Besides $\mathrm{pH}$, the stability of the complexes is affected by the type of central ion and by the properties of the ligand (Filep, 1999). For transition metals with unsaturated d orbital $\left(\mathrm{Mn}^{2+}, \mathrm{Mn}^{3+}, \mathrm{Fe}^{2+}, \mathrm{Fe}^{3+}, \mathrm{Co}^{2+}, \mathrm{Ni}^{2+}, \mathrm{Cu}^{2+}, \mathrm{Zn}^{2+}, \mathrm{Cr}^{3+}\right)$, the dative (coordinative) bonds are dominant in their complex compounds. The higher the oxidation state, the more stable is the complex with the ligand (Filep, 1999).

The trend to form complexes between metal and ligands in soils can be explained based on the principle of hard, soft acid and base (HSAB). A Lewis acid is any chemical species that employs an empty electronic orbital in initiating a complexation reaction, while a Lewis base is any chemical species that employs a doubly occupied electronic orbital in initiating a complexation reaction. The proton and all of the metal cations of interest in soil solutions are Lewis acids (Table 3 ). The Lewis bases include $\mathrm{HO}_{2} \mathrm{O}$, oxyanions such as $\mathrm{OH}, \mathrm{COO}^{-}, \mathrm{CO}_{2}^{-}, \mathrm{SO}_{4}^{2-}$, $\mathrm{PO}_{4}^{2-}$, and inorganic $\mathrm{N}, \mathrm{S}$ and $\mathrm{P}$ electron donors. The $\mathrm{HSAB}$ divides Lewis acids and bases according to the following categories:

a) Hard Lewis acid: is a molecular unit of relatively small size, high oxidation state, high electronegativity, and low polarizability. They have outer electrons relatively difficult to excite to higher energies;

b) Soft Lewis acid: is of relatively large size, low oxidation state, low electronegativity, and high polarizabil-

\begin{tabular}{|c|c|c|}
\hline \multirow{2}{*}{ Metal } & \multicolumn{2}{|r|}{ Principle species } \\
\hline & Acid soils & Alkaline Soils \\
\hline $\mathrm{Mn}(\mathrm{II})$ & $\mathrm{Mn}^{2+}, \mathrm{MnSO}_{4}{ }^{0}, \mathrm{Org}$ & $\mathrm{Mn}^{2+}, \mathrm{MnSO}_{4}{ }^{0}, \mathrm{MnCO}_{3}{ }^{0}, \mathrm{MnHCO}_{3}{ }^{+}, \mathrm{MnB}(\mathrm{OH})_{4}^{+}$ \\
\hline $\mathrm{Fe}(\mathrm{II})$ & $\mathrm{Fe}^{2+}, \mathrm{FeSO}_{4}{ }^{0}, \mathrm{FeH} 2 \mathrm{PO}_{4}^{+}$ & $\mathrm{Fe}^{2+}, \mathrm{FeCO}_{3}{ }^{0}, \mathrm{FeHCO}_{3}{ }^{+}, \mathrm{FeSO}_{4}{ }^{0}$ \\
\hline $\mathrm{Ni}(\mathrm{II})$ & $\mathrm{Ni}^{2+}, \mathrm{NiSO}_{4}^{0}, \mathrm{NiHCO}_{3}^{+}$, Org & $\mathrm{NiCO}_{3}{ }^{0}, \mathrm{NiHCO}_{3}^{+}, \mathrm{Ni}^{+2}, \mathrm{NiB}(\mathrm{OH})_{4}^{+}$ \\
\hline $\mathrm{Cu}(\mathrm{II})$ & Org, $\mathrm{Cu}^{2+}$ & $\mathrm{CuCO}_{3}{ }^{0}, \mathrm{Org}, \mathrm{CuB}(\mathrm{OH})_{4}^{+}, \mathrm{Cu}\left(\mathrm{B}(\mathrm{OH})_{4}\right)_{2}^{0}$ \\
\hline $\mathrm{Zn}(\mathrm{II})$ & $\mathrm{Zn}^{2+}, \mathrm{ZnSO}_{4}{ }^{0}$ & $\mathrm{ZnHCO}_{3}^{+}, \mathrm{ZnCO}_{3}^{0}, \mathrm{Zn}^{2+}, \mathrm{ZnSO}_{4}^{0}, \mathrm{ZnB}(\mathrm{OH})_{4}^{+}$ \\
\hline $\mathrm{Cd}(\mathrm{II})$ & $\mathrm{Cd}^{2+}, \mathrm{CdSO}_{4}^{0}, \mathrm{CdCl}^{+}$ & $\mathrm{Cd}^{2+}, \mathrm{CdCl}^{+}, \mathrm{CdSO}_{4}^{0}, \mathrm{CdHCO}_{3}^{+}$ \\
\hline $\mathrm{Pb}(\mathrm{II})$ & $\mathrm{Pb}^{2+}$, Org, $\mathrm{PbSO}_{4}{ }^{0}, \mathrm{PbHCO}_{3}^{+}$ & $\mathrm{PbCO}_{3}^{0}, \mathrm{PbHCO}_{3}^{+}, \mathrm{Pb}\left(\mathrm{CO}_{3}\right)_{2}^{2-}, \mathrm{PbOH}^{+}$ \\
\hline
\end{tabular}
ity. They have outer electrons relatively easy to excite to higher energies;

Table 2 - Main chemical species of trace metals in acid and alkaline soil solutions (oxic conditions). (Adapted from Sposito, 1983). 
Table 3 - Representative hard and soft Lewis acids and bases. (Sposito, 1994)

\begin{tabular}{l}
\hline LEWIS ACIDS \\
\hline Hard Acids \\
$\mathrm{H}^{+}, \mathrm{Li}^{+}, \mathrm{Na}^{+}, \mathrm{K}^{+},\left(\mathrm{Rb}^{+}, \mathrm{Cs}^{+}\right), \mathrm{Mg}^{2+}, \mathrm{Ca}^{2+}, \mathrm{Sr}^{2+},\left(\mathrm{Ba}^{2+}\right), \mathrm{Ti}^{4+}, \mathrm{Zr}^{4+}, \mathrm{Cr}^{3+}, \mathrm{Cr}^{6+}, \mathrm{Mn}^{4+}, \mathrm{Mn}^{3+}, \mathrm{Mn}^{2+}, \mathrm{Fe}^{3+}, \mathrm{Co}^{3+}, \mathrm{Al}^{3+}, \mathrm{Si}^{4+}, \mathrm{CO}_{2}$ \\
Borderline Acids \\
$\mathrm{Fe}^{3+}, \mathrm{Co}^{2+}, \mathrm{Ni}^{2+}, \mathrm{Cu}^{2+}, \mathrm{Zn}^{2+},\left(\mathrm{Pb}^{2+}\right)$ \\
Soft Acids \\
$\mathrm{Cu}^{+}, \mathrm{Ag}^{+}, \mathrm{Au}^{+}, \mathrm{Cd}^{2+}, \mathrm{Hg}+, \mathrm{Hg}^{2+}, \mathrm{CH}_{3} \mathrm{Hg}^{2+}$ \\
$\mathrm{LEWIS} \mathrm{BASES}^{\text {BHard Bases }}$ \\
$\mathrm{NH}_{3}, \mathrm{RNH}_{2}, \mathrm{H}_{2} \mathrm{O}, \mathrm{OH}^{-}, \mathrm{O}^{2-}, \mathrm{ROH}^{2+} \mathrm{CH}_{3} \mathrm{COO}, \mathrm{CO}_{3}{ }^{2-}, \mathrm{NO}_{3}^{-}, \mathrm{PO}_{4}^{3-}, \mathrm{SO}_{4}^{2-}, \mathrm{F}^{-}$ \\
Borderline Bases \\
$\mathrm{C}_{6} \mathrm{H}_{5} \mathrm{NH}_{2}, \mathrm{C}_{2} \mathrm{H}_{5} \mathrm{~N}, \mathrm{~N}_{2}, \mathrm{NO}_{2}^{-}, \mathrm{SO}_{3}^{2-}, \mathrm{Br}^{-},(\mathrm{Cl})$ \\
Soft Bases \\
$\mathrm{C}_{2} \mathrm{H}_{4}, \mathrm{C}_{6} \mathrm{H}_{6}, \mathrm{R}_{3} \mathrm{P},(\mathrm{RO})_{3} \mathrm{P}^{2}, \mathrm{R}_{3} \mathrm{As}, \mathrm{R}_{2} \mathrm{~S}, \mathrm{RSH}_{2} \mathrm{~S}_{2} \mathrm{O}_{3}^{-}, \mathrm{S}^{2-}, \mathrm{I}^{-}$
\end{tabular}

$\mathrm{R}=$ organic molecular unit; ( ) indicates tendency to softness

c) Hard Lewis base: is a molecular unit of high electronegativity and low polarizability. It tends to be difficult to oxidize and does not posses low-energy, empty electronic orbitals;

d) Soft Lewis base: has low electronegativity, high polarizability and a proclivity toward oxidation.

The separation of hard acids or bases from soft ones is not sharp. There is a gradual change as the polarizability of a Lewis acid increases. After the metal-ligand complex formation, others ligands may compete to destabilize it and form new complexes with the metal cation (Sposito, 1994).

The HSAB principle indicates that hard acids tend to form complexes with hard bases. On the other hand, soft acids have higher affinity to form complexes with soft bases. This principle, although empirical, can lead to the conclusion that speciation of trace metals will depend more on the content and type of organic matter present in soil.

Free-metal species are generally bioavailable, and their determination reflects the equilibrium among different chemical species. Free metal cations are more toxic than the same metals in soluble complexed forms (McBride, 1995).

Many methods have been developed to quantify "free-metal" activities (Norvell, 1971; Gardiner, 1974; Baker et al., 1977; Fujii et al., 1983; Amacher, 1984; Fitch \& Helmke, 1989; Hirsch \& Bonin, 1990). Studying different methods to determine Cd activities in soil solution, Candelaria et al. (1995) found that metal activities in biosolid- treated soils could be estimated by the GEOCHEM-PC program (Sposito \& Mattigod, 1980; Parker et al., 1995). This model calculates the speciation of an equilibrium solution using thermodynamic stability constants and total metal and ligand concentrations.
For each component of a soil solution, a mole balance equation is set up, and thermodynamic equilibrium constants corrected for ionic strength are incorporated into the various terms of this equation according to the law of mass action (Sposito, 1983). Currently, there are many softwares that are capable to calculate ion activity in solution, such as SOILCHEM (Sposito \& Coves, 1988), MINTEQA2 and MINEQL. One of the most important advantages to use computer-based chemical equilibrium models, is to predict the distribution of metal species in soils.

\section{REFERENCES}

AHUMADA, I.; MENDOZA, J.; ESCUDERO, P.; ASCAR, L. Effect of acetate, citrate, and lactate incorporation on distribution of cadmium and copper chemical forms in soil. Communications in Soil Science and Plant Analysis, v.32, p.771-785, 2001.

ALLEONI, L.R.F.; CAMARGO, O.A. Pontos de efeito salino nulo de latossolos ácricos. Revista Brasileira de Ciência do Solo, v.18, p.175180, 1994a.

ALLEONI, L.R.F.; CAMARGO, O.A. Atributos físicos de latossolos ácricos do norte paulista. Scientia Agricola, v.51, p.321-326, 1994 b.

ALLEONI, L.R.F.; CAMARGO, O.A. Óxidos de ferro e de alumínio, e mineralogia da fração argila deferrificada de latossolos ácricos. Scientia Agricola, v.53, p.416-421, 1995.

ALLOWAY, B.J. Heavy metals in soils . New York: Wiley, 1990. 339p.

AMACHER, M.C. Determination of ionic activities in soil solutions and suspensions - principal limitations. Soil Science Society of America Journal, v.48, p. 519-524, 1984.

ANTONIADIS, V.; ALLOWAY, B.J. Availability of Cd, Ni and Zn to ryegrass in sewage sludge-treated soils at different temperatures. Water, Air and Soil Pollution, v.132, p.201-214, 2001.

ANTONIADIS, V.; ALLOWAY, B.J. Evidence of heavy metal movement down the profile of a heavily-sludged soil. Communications in Soil Science and Plant Analysis, v.34, p.1225-1231, 2003.

BAKER, D.E.; AMACHER, M.C.; DOTY, W.T. Monitoring sewage sludge, soils and crops for zinc and cadmium. In: LOEHR, R.C. (Ed.) Land as a waste management alternative . Ann Arbor: Ann Arbor Scientific, 1977.p.261-281.

BARROW, N.J. Reactions of anions and cations with variable-charge soils. Advances in Agronomy, v.38, p.183-229, 1985. 
BARRY, G.A.; CHUDEK, P.J.; BEST E.K.; MOODY, P.W. Estimating sludge application rates to land based on heavy metal and phosphorus sorption characteristics of soil. Water Research, v.29, p.2031-2034, 1995.

BERGLUND, S.; DAVIS, R.D.; L'HERMITE, P. Utilization of sewage sludge on land: rates of application and long-term effects of metals. Dordrecht: D. Reidel Publishing, 1984. 216p.

BOLAN, N.S.; DURAISAMY, V.P. Role of inorganic and organic soil amendments on immobilisation and phytoavailability of heavy metals: a review involving specific case studies. Australian Journal of Soil Research, v.41, p.533-555, 2003.

BOLAN, N.S.; ADRIANO, D.C.; CURTIN, D. Soil acidification and liming interactions with nutrient and heavy metal transformation and bioavailability. Advances in Agronomy, v.78, p.215-272, 2003a.

BOLAN, N.S.; ADRIANO, D.C.; MANI, P.A.; DURAISAMY, A. Immobilization and phytoavailability of cadmium in variable charge soils. II. Effect of lime addition. Plant and Soil, v.251, p.187-198, 2003b.

BURTON, E.D.; HAWKER, D.W.; REDDING, M.R. Estimating sludge loadings to land based on trace metal sorption in soil: effect of dissolved organo-metallic complexes. Water Research, v.37, p.1394-1400, 2003.

CAJUSTE, L.J.; CRUZ-DIAZ, J.; GARCIA-OSORIO, C. Extraction of heavy metals from contaminated soils: I. Sequential extraction in surface soils and their relationships to DTPA extractable metals and metal plant uptake. Journal of Environmental Science and Health. Part A-Toxic/ Hazardous Substances \& Environmental Engineering, v.35, p.1141$1152,2000$.

CANDELARIA, L.M.; CHANG, A.C.; AMRHEIN, C. Measuring cadmium ion activities in sludge-amended soil.Soil Science, v.159, p.162-175, 1995.

CHANG, A.C.; HYUN, H.; PAGE, A.L. Cadmium uptake for Swiss chard grown on composted sewage sludge treated field plots: plateau or time bomb? Journal of Environmental Quality, v.26, p.11-19, 1997.

CHAO, T.T.; ZHUO, L. Extraction techniques for selective dissolution of amorphous iron oxides from soils and sediments. Soil Science Society of America Journal, v.47, p.225-232, 1983.

CORNELL, R.M.; SCHWERTMANN, U. The iron oxides. Weinheim: VHC Publishers, 1996. 573p.

DIAS, N.M.P.; ALLEONI, L.R.F.; CASAGRANDE, J.C.; CAMARGO, O.A. Adsorção de cádmio em Latossolos ácricos. Revista Brasileira de Ciência do Solo, v.25, p.297-304, 2001a.

DIAS, N.M.P.; ALLEONI, L.R.F.; CASAGRANDE, J.C.; CAMARGO, O.A. Isotermas de adsorção de cádmio em Latossolos ácricos. Revista Brasileira de Engenharia Agrícola e Ambiental, v.5, p.229-234, 2001b.

DIAS, N.M.P.; ALLEONI, L.R.F.; CASAGRANDE, J.C.; CAMARGO, O.A. Energia livre da reação de adsorção de cádmio em solos. Ciên cia Rural, v.33, p.829-834, 2003.

FILEP, G. Soil chemistry. Processes and constituents. Budapeste: Akadémiai Kiadó, 1999. 330p.

FITCH, A.; HELMKE, P. Donan equilibrium/graphite furnace atomic absorption estimates of soil extract complexation capacities. Analytica Chimica Acta,v.61,p.1295-1298, 1989.

FORD, R.G.; BERTSCH, P.M.; FARLEY, K.J. Changes in transition and heavy metal partitioning during hydrous iron oxide aging. Environmental Science and Technology, v.31, p.2028-2033, 1997

FUJII, R.; HENDRICKSON, L.L.; COREY, R.B. Ionic activities of trace metals in sludge-amended soils. Science of the Total Environment, v.28, p.179-190, 1983.

GARDINER, J. The chemistry of cadmium in natural water -I . A study of cadmium complex formation using the cadmium specific - ion electrode. Water Research, v.8, p.23-30, 1974

GOMES, P.C.; FONTES, M.P.F.; SILVA, A.G.; MENDONÇA, E.D.; NETTO, A.R. Selectivity sequence and competitive adsorption of heavy metals by Brazilian soils. Soil Science Society of America Journal, v.65, p.1115-1121, 2001.

HARMSEN, K.; VLEK, P.L.G. The chemistry of micronutrients cations in a group of loessial grassland soils of New Zealand. Geoderma, v.83, p.53-62, 1985.

HIRSCH, D.; BONIN, A. Cadmium speciation in soil solutions. Journal of Environmental Quality, v.19, p.366-372, 1990

Hyun, H.; Chang, A.C.; Parker, D.R.; Page, A.L. Cadmium solubility and phytoavailability in sludge-treated soils: Effects of soil organic carbon. Journal of Environmental Quality, v.27, p.329-334, 1998
IMPELLITTERI, C.A.; ALLEN, H.E.; YIN, Y.; YOU, S.J.; SAXE, J.K. Soil properties controlling metal partitioning. In: SELIM, H.M.; SPARKS, D.L. (Ed.)Heavy metals release in soils . New York: Lewis Publishers, 2001. p.149-165.

JI, G.L.; LI, H.Y. Electrostatic adsorption of cations. In: YU, T.R. (Ed.) Chemistry of variable charge soils. New York: Oxford University Press, 1997. p.64-111.

KABATA-PENDIAS, A.; PENDIAS, H. Soils and soil processes. In: PENDIAS, A. (Ed.) Trace elements in soils and plants. Boca Raton: CRC Press, 1984. 315p.

KARAPANAGIOTIS, N.; STERRITT, R.; LESTER, J.N. Heavy metals complexation in sludge-amended soil. The role of organic matter in metal retention. Environmental Technology,v.12,p.1107-1116, 1991.

KIEKENS, L. Behavior of heavy metals in soils. In: BERGLUND, S.; DAVIS, R.D.; L HERMITE, P. (Ed.) Utilization of sewage sludge on land: rates of application and long-term effects of metals. Dordrecht: D. Reidel Publishing, 1983.

KIIKKILA, O.; PENNANEN, T.; PERKIOMAKI, J.; DEROME, J.; FRITZE, H. Organic material as a copper immobilising agent: a microcosm study on remediation. Basic and Applied Ecology, v.3, p.245-253, 2002.

LINDSAY, W.L. Chemical equilibria in soils . New York: Wiley, 1979.

LOMBI, E.; GERZABEK, M.H. Determination of mobile heavy metal fraction in soil: result of a plot experiment with sewage sludge. Communications in Soil Science and Plant Analysis, v.29, p.2545-2556, 1998.

LÓPEZ-MOSQUERA, M.E.; MOIRÓN, C.; CARRAL, E. Use of dairyindustry sludge as fertilizer for grasslands in northwest Spain: heavy metal level in the soil and plant.Resource, Conservation and Recycling, v.30, 95-109, 2000

MARTINÉZ, C.E.; McBRIDE, M.B. Solubility of $\mathrm{Cd}, \mathrm{Cu}, \mathrm{Pb}$ and $\mathrm{Zn}$ in aged coprecipitates with amorphous iron hydroxides. Environmental Science and Technology, v.32, p.743-748, 1998.

MARTIN-NETO, L.; NASCIMENTO, O.R.; TALAMONI, J.; POPPI, N.R. EPR of micronutrients-humic substances complexes extracted from a Brazilian soil. Soil Science, v.151, p.369-376, 1991.

MATTIGOD, S.V.; PAGE, A.L. Assessment of metal pollution in soil. In: THORNTON, I. (ed.) Applied environmental geochemistry. London: Academic Press, 1983. cap.12, p.355-394.

McBRIDE, M.B. Reactions controlling heavy metal solubility in soils. In: STEWART, B.A. (Ed.) Advances in Soil Science . New York: SpringerVerlag, 1989. p.1-56

McBRIDE, M.B. Toxic metal accumulation from agricultural use of sludge: are USEPA regulations protective? Journal of Environmental Quality, v.24, p.5-18, 1995.

McBRIDE, M.B. Growing food crops on sludge-amended soils: problems with U.S. environmental protection agency method of estimating toxic metal transfer. Environmental Toxicology and Chemistry, v.17, p.22742281, 1998.

McBRIDE, M.B.; MARTINEZ, C.E.; TOPP, E.; EVANS, L. Trace metal solubility and speciation in a calcareous soil 18 years after no-till sludge application. Soil Science, v.165, p.646-656, 2000.

McBRIDE, M.B.; RICHARDS, B.K.; STEENHUIS, T.; RUSSO, J.J.; SAUVE, S. Mobility and solubility of toxic metals and nutrients in soil fifteen years after sludge application.Soil Science, v.162, p.487-500, 1997.

MESQUITA, M.E.; CARRANCA, C.; MENINO, M.R. Influence of pH on copper - zinc competitive adsorption by a sandy soil. Environmental Technology, v.23, p.1043-1050, 2002.

MOOLENAAR, S.W.; BELTRAMI, P. Heavy metal balances of an Italian soil as affect by sewage sludge and Bordeaux mixture applications. Journal of Environmental Quality, v.27, p.828-835, 1998

NORVELL, W.A. Equilibria of metal chelates in soil solution. In: MORTVEDT, J.J.; GIORDANO, P.M.; LINDSAY, W.L. (Ed.) Micronutrients in agriculture . Madison: SSSA, 1971. p.115-138.

OBRADOR, A.; RICO, M.I.; MINGOT, J.I.; ALVAREZ, J.M. Metal mobility and potential bioavailability in organic matter-rich soil-sludge mixtures: effect of soil type and contact time. The Science of the Total Environment, v.206, p.117-126, 1997.

OHTANI, T.; UEMATSU, N.; YASHIMA, S.; FUKAMI, M. Effect of anions in simulated precipitation on the uptake of heavy metals and aluminum by Brassica rapa L. grown in heavy-metal-contaminated sandy soil. Water, Air and Soil Pollution, v.130, p.751-756, 2001 
OLAJIRE, A.A.; AYODELE, E.T.; OYEDIRDAN, G.O.; OLUYEMI, E.A. Levels and speciation of heavy metals in soils of industrial southern Nigeria. Environmental Monitoring and Assessment v.85, p.135-155, 2003.

OLIVEIRA, F.C.; MATTIAZZO, M.E. Metais pesados em Latossolo tratado com lodo de esgoto e em plantas de cana-de-açúcar. Scientia Agricola, v.58, p.581-593, 2001.

PARKER, D.R.; NORVELL, W.A.; CHANEY, R.L. GEOCHEM-PC: A chemical speciation program for IBM and compatible personal computers. In: LIPPERT, R.H. (Ed.) Soil chemical equilibria and reaction models. Madison: SSSA, 1995. p.253-169. (Special Publication, 42).

PIERANGELI, M.A.P.; GUILHERME, L.R.G.; OLIVEIRA, L.R.; CURI, N.; SILVA, M.L.N. Efeito da força iônica da solução de equilíbrio sobre a adsorção-dessorção de chumbo em Latossolos brasileiros. Pesquisa Agropecuária Brasileira,v.36,p.1077-1084, 2001.

PIERANGELI, M.A.P.; GUILHERME, L.R.G.; OLIVEIRA, L.R.; CURI, N.; SILVA, M.L.N. Efeito da força iônica da solução de equilíbrio na adsorção de cádmio em Latossolos brasileiros. Pesquisa Agropecuária Brasileira, v.38, p.737-745, 2003.

PINHEIRO-DICK, D.; SCHWERTMANN, U. Microaggregates from Oxisols and Inceptisols: dispersion through selective dissolutions and physicochemical treatments. Geoderma, v.74, p.49-63, 1996.

PIRES, A.M.M.; MATTIAZZO, M.E. Biosolids conditioning and the availability of $\mathrm{Cu}$ and $\mathrm{Zn}$ for rice. Scientia Agricola, v.60, p.161-166, 2003.

SALAM, A.K.; HELMKE, P.A. The $\mathrm{pH}$ dependence of free ionic activities and total dissolved concentrations of copper and cadmium in soil solution. Geoderma, v.83, p.281-291, 1998.

SASTRE, I.; VICENTE, M.A.; LOBO, M.C. Behaviour of cadmium and nickel in a soil amended with sewage sludge. Land Degradation and Development, v.12, p.27-33, 2001.

SAUVE, S.; NORVELL, W.A.; MCBRIDE, M.; HENDERSHOT, W. Speciation and complexation of cadmium in extracted soil solutions. Environmental Science \& Technology, v.34, p.291-296, 2000.

SCHAECKE, W.; TANNEBERG, H.; SCHILLING, G. Behavior of heavy metals from sewage sludge in a Chernozem of the dry belt in SaxonyAnhalt/Germany. Journal of Plant Nutrition and Soil Science, v.165, p.609-617, 2002.

SCHMIDT, J.P. Understanding phytotoxicity thresholds for trace elements in land-applied sewage-sludge. Journal of Environmental Quality, v.26, p.4-10, 1997.

SCHWERTMANN, U. Solubility and dissolution of iron oxides. Plant and Soil, v.130, p.1-25, 1991.

SCHWERTMANN, U.; PHILIPPE, C.; MURAD, E. Properties of goethite varying crystallinity. Clays and Clay Minerals, v.33, p.369-378, 1985.

SCHWERTMANN, U.; TAYLOR, R.M. Iron oxides. In: DIXON, J.B.; WEED, S.B. (Ed.) Minerals in soils environments. Madison: SSSA, 1977. p.145-179.

SHUMAN, L.M.; DUDKA, S.; DAS, K. Cadmium forms and plant availability in compost-amended soil. Communications in Soil Science and Plant Analysis, v.33, p.737-748, 2002.

SILVA, J.C.G.E.; OLIVEIRA, C.J.S. Metal ion complexation properties of fulvic acids extracted from composted sewage sludge as compared to a soil fulvic acid. Water Research, v.36, p.3404-3409, 2002.

SILVEIRA, M.L.A.; ALLEONI, L.R.F.; CASAGRANDE, J.C.; CAMARGO, O.A. Energia livre da reação de adsorção de cobre em latossolos ácricos. Scientia Agricola, v.56, p.1117-1122, 1999.

SILVEIRA, M.L.A.; ALLEONI, L.R.F.; CASAGRANDE, J.C.; CAMARGO, O.A. Copper adsorption in oxidic soils after removal of organic matter and iron oxides. Communications in Soil Science and Plant Analysis, v.33, p.3581-3592, 2002.

SINGH, B.; GILKES, R.J. Properties and distribution of iron oxides and their association with minor elements in the soils of South-Western Australia. Journal of Soil Science, v.43, p.77-98, 1992.

SPARKS, D.L. Environmental soil chemistry . San Diego: Academic Press, 1995. 267p.
SPOSITO, G. Chemical equilibria and kinetics in soils. New York: Oxford University Press, 1994.

SPOSITO, G. The chemical forms of trace metals in soils. In: THORNTON, I. Applied environmental geochemistry. London: Academic Press, 1983.p.123-170.

SPOSITO, G.; MATTIGOD, S.V. A computer program for the calculation of chemical equilibria in soil solutions and other natural water systems. Riverside: University of California; The Kearney Foundation of Soil Science, 1980.

SPOSITO, G.; COVES, J. A computer program for the calculation of chemical speciation in soils . Riverside: University of California; The Kearney Foundation of Soil Science, 1988.

TOMLIN, A.D.; PROTZ, R.; MARTIN, R.R.; McCABE, D.C. Relationships amongst organic matter content, heavy metal concentrations, earthworm activity and soil microfabric on a sewage sludge disposal site. Geoderma, v.57, p.89-103, 1993.

TSADILAS, C.D.; MATSI, T.; BARBAYIANNIS, N.; DIMOYIANNIS, D. Influence of sewage sludge application on soil properties and on the distribution and availability of heavy metal fractions. Communications in Soil Science and Plant Analysis, v.26, p.2603-2619, 1995.

TURKDOGAN, M.K.; KILICEL, F.; KARA, K.; TUNCER, I.; UYGAN, I. Heavy metals in soil, vegetables and fruits in the endemic upper gastrointestinal cancer region of Turkey. Environmental Toxicology and Pharmacology, v.13, p.175-179, 2003.

UNITED STATES. Environmental Protection Agency. Standards for the use or disposal of sewage sludge: final rules. Federal Register, v.59, p.9248-9404, 1993.

UNITED STATES. Environmental Protection Agency.A plain english guide to the EPA part 503 biosolids rule. Washington: EPA Office of Wastewater Management, 1994.

VEERESH, H.; TRIPATHY, S.; CHAUDHURI, D.; BART B.R.; POWELL M.A. Competitive adsorption behavior of selected heavy metals in three soil types of India amended with fly ash and sewage sludge. Environmental Ecology, v.44, p.363-370, 2003.

VULKAN, R.; MINGELGRIN, U.; BEN-ASHER, J.; FRENKEL, H. Copper and zinc speciation in the solution of a soil-sludge mixture. Journal of Environmental Science, v.31, p.193-203, 2002.

WANG, Q.R.; CUI, Y.S.; LIU, X.M.; DONG, Y.T.; CHRISTIE, P. Soil contamination and plant uptake of heavy metals at polluted sites in China. Journal of Environmental Science and Health. Part A-Toxic/ Hazardous Substances \& Environmental Engineering, v.38, p.823838, 2003.

WANG, Q.R.; CUI, Y.S.; LIU, X.M.; DONG, Y.T.; CHRISTIE, P. Soil contamination and plant uptake of heavy metals at polluted sites in China. Journal of Environmental Science and Health Part A - Toxic/ Hazardous Substances \& Environmental Engineering, v.38, p.823838, 2003.

WHATMUFF, M.S. Applying biosolids to acid soils in New South Wales: are guideline soil metal limits from other countries appropriate? Australian Journal of Soil Research, v.40, p.1041-1056, 2002.

YOO, M.S.; JAMES, B.R. Zinc extractability as a function of $\mathrm{pH}$ in organic waste-amended soils. Soil Science, v.167, p.246-259, 2002.

YU, T.R.; SUN, H.Y.; ZHANG, H. Specific adsorption of cations. In: YU, T.R. (Ed.) Chemistry of variable charge soils. New York: Oxford University Press, 1997. p.140-174.

ZHANG, X.N.; ZHAO, A.Z. Surface Charge. In: YU, T.R. (Ed.) Chemistry of variable charge soils. New York: Oxford University Press, 1997. p.64-111.

Received March 28, 2003

Accepted September 03, 2003 